\title{
FACTORS INFLUENCING THE UTILISATION OF PREVENTION OF MOTHER-TO-CHILD- TRANSMISSION (PMTCT) SERVICES BY PREGNANT WOMEN IN THE EASTERN CAPE, SOUTH AFRICA
}

\author{
Karl Peltzer \\ Ph D \\ Chief Research Specialist, Human Sciences Research Council \& University of Venda \\ Corresponding author:KPeltzer@hsrc.ac.za \\ Donald Skinner \\ Ph D \\ Chief Research Specialist, Human Sciences Research Council
}

\section{Sakhumzi Mfecane}

MA

Senior Researcher, Human Sciences Research Council

\section{Olive Shisana}

DSc

Executive Director, Human Sciences Research Council

\section{Ayanda Nqeketo}

MA Intern

Junior Researcher, Human Sciences Research Council

\author{
Thabang Mosala \\ Ph D \\ Chief Research Specialist, Human Sciences Research Council
}

Key words: Utilization; PMTCT services; Eastern Cape; South Africa

\section{OPSOMMING}

Die doel van die studie was om faktore te identifiseer wat die benutting van die Voorkoming van Moeder-tot-Kind Oordrag (VMTKO) beïnvloed in 'n omgewing in Suid-Afrika wat arm is aan hulpbronne. ' $n$ Steekproef van 186 swanger vroue (29.6\% MIV-positief, en $70.4 \%$ negatief) in vier klinieke in 'n plattelandse distrik in die Oos-Kaap het as deel van die VMTKO-program aan onderhoude deelgeneem nadat hulle die resultate van hulle MIV-toetse ontvang het. Wat die infrastruktuur betref het die meeste vroue nie vervoer gehad na 'n gesondheidsfasiliteit nie en ook geen kommunikasie daarmee gehad nie. Meer as $90 \%$ van die vroue was tevrede met die MIV-berading wat hulle ontvang het. Meeste vroue (54\%) was van mening dat hulle gedurende swangerskap hoofsaaklik ondersteuning van hulle moeders en/of eggenoot/gesel (50\%) ontvang het. Meeste swanger vroue (92\%) het verkies om in die hospitaal geboorte te skenk terwyl $8 \%$ verkies het om by die huis die lewe te skenk, meestal met die hulp van 'n tradisionele helper by geboortes. Twee-derdes van die MIV-positiewe vroue het gemeld dat hulle hulle babas slegs met formulemelk sou voed. Die houding van die gemeenskap teenoor persone wat met MIVIVIGS leef is meestal as negatief waargeneem. Faktore wat die benutting van VMTKO beïnvloed (dit is die aanvaarding van antiretrovirale terapie aan HIV-positiewe vroue, 'n fasiliteitsgebaseerde bevalling, en die verkleefdheid aan "neem huistoe" ART wat vir die moeder en pasgeborene geïdentifiseer is), sluit in: (1) MIV-berading deur gesondheidsorgpersoneel, (2) fisiese toegang tot ' $n$ gesondheidsfasiliteit, (3) gesin- en gemeenskapsondersteuning, (4) stigma, (5) verlossingsvoorkeur, en (6) voedingsvoorkeure van die suigeling. 


\section{SUMMARY}

The aim of the study was to identify factors influencing the utilisation of Prevention of Mother-to-Child Transmission (PMTCT) in a resource poor setting in South Africa. A sample of 186 pregnant women (29.6\% HIV positive and $70.4 \%$ HIV negative) in four clinics in a rural district in the Eastern Cape were interviewed as part of the PMTCT programme after they had received their HIV test results. Regarding infrastructure, most women lacked transport to and communication with a health facility. More than $90 \%$ felt that they had received adequate information on most of the components of the PMTCT programme. About $90 \%$ of the women were satisfied with the HIV counselling they had received. Most women (54\%) felt they would receive support during their pregnancy mainly from their mothers, and/or husband/partner (50\%). Most pregnant women (92\%) preferred to give birth in hospital, while $8 \%$ prefer to deliver at home, mostly with the assistance of a traditional birth attendant (TBA). Two-thirds of the HIV positive women stated they would feed their babies with formula milk only. Community attitudes towards people living with HIV/AIDS were mostly perceived as negative. Factors influencing the utilisation of PMTCT (that is the acceptance of antiretroviral therapy to HIV positive women, facility-based delivery, and adherence to "take-home" ART identified for mother and newborn), included: (1) HIV counselling by health care staff, (2) physical access to a health facility, (3) family and community support, (4) stigma, (5) delivery preference, and (6) infant feeding preferences.

\section{INTRODUCTION}

Mother-to-child transmission (MTCT) is by far the largest source of HIV infection in children below the age of 15 years. An estimated 200 million women around the world become pregnant each year, of which about 2.5 million are HIV-positive (UNAIDS, 2002:5f.). At least half a million infants and children have already died from AIDS, undermining child survival gains made in earlier years through comprehensive child health programmes (UNICEF, 2003:8). Based on annual antenatal surveillance, approximately $34.5 \%$ of pregnant women between 25 and 29 years were HIV-positive, and about $29.5 \%$ of pregnant women aged 30 to 34 were living with the virus in South Africa in 2001. The overall HIV prevalence among antenatal care attendees for the Eastern Cape Province of South Africa has risen to 27.1\% in 2003 (Department of Health, 2003:10). It is also estimated that, in the Eastern Cape Province, there are 50,000 HIV positive children who acquired their infection from their mothers (Department of Health, 2000:5).

The South African Cabinet, following a High Court ruling initiated by the Treatment Action Campaign (TAC), decided to roll out the programme to prevent transmission of HIV from mother to child (PMTCT) in all health facilities that have an appropriate infrastructure. The treatment will thus be extended beyond the current experimental sites to all who need it. However, for this programme to be effective, certain standards have to be met as outlined in the WHO (2001:2) draft guidelines for the Prevention of Mother-to-Child Transmission Programme. These guidelines include:

- expansion and strengthening of family planning and STI/HIV information and services, especially of those approaches which provide dual protection;

- early access to quality ante-natal care from trained health workers;

- counselling and HIV testing for women and their partners;

- provision of antiretroviral therapy during pregnancy and delivery for HIV positive women;

- improved care during labour, delivery and the postpartum period;

- counselling for HIV positive women on infant feeding choices and support for whatever option they choose,

- adequate mother-child care services; and

- a conducive and confidential Voluntary Counselling and Testing (VCT) environment.

\section{RESEARCH PROBLEM}

These $\mathrm{WHO}$ guidelines are demanding and require that a health care facility be fully equipped if it is to effectively provide PMTCT services. However, in South Africa, the majority of health care facilities do not meet this standard. Problems like staff shortage, poor delivery of medication, lack of proper consultation and counselling rooms, are experienced in several health insti- 
tutions throughout the country. This project sought to investigate factors that may influence the utilisation of PMTCT services by pregnant women in the Eastern Cape Province, a poorly-resourced province of South Africa. This study sought to investigate pregnant women whose HIV status had just been confirmed so as to study in particular factors influencing their participation in the prevention of mother-to-child transmission of HIV.

\section{RESEARCH QUESTION}

The research question guiding the study was: What are factors influencing utilisation of PMTCT services by pregnant women?

\section{RESEARCH AIM}

The study aimed at identifying factors influencing utilisation of PMTCT services by pregnant women in a resource poor setting, in particular aspects of PMTCT services relating to:

- acceptance of antiretroviral therapy (ART) by HIV positive women;

- use of facility-based delivery where improved obstetric practices are utilised, and supervision of ART for mother and newborn; and

- adherence to "take-home" ART for mother and newborn when given to HIV positive women at Ante Natal Classes (ANC).

\section{SIGNIFICANCE OF THE STUDY}

It is crucial that factors influencing the utilisation of PMTCT services in a resource poor setting should be studied. This is particularly important in the context of South Africa where health resources are unevenly distributed between rural and urban areas, including distribution of health providers. Certain health institutions in the rural areas still lack basic resources for provision of good health care.

In South Africa an evaluation of PMTCT in pilot sites found that it is feasible to implement PMTCT but that there are also numerous operational challenges for establishing and expanding a PMTCT programme under routine health service conditions.

In some part this is due to supply side issues such as overburdened staff. But in a major part, there is a lack of demand for women to accept all the services that make up PMTCT programmes. The medical recommendations made in PMTCT programmes are often difficult for women to implement as they are overshadowed by community norms, values and beliefs. Women's decision to participate fully in a PMTCT programme is influenced by the opinions of their partners, as well as other family and community members. Also, this decision is influenced by women's perceptions and fear of possible negative reactions by others. Partners, parents, in-laws, and other relatives have varying degrees of influence about testing, disclosure and drug treatment, and often have significant authority over infant feeding. And if women are able to decide on their own to adhere to all of the recommended practices, they are going against social norms. A clear example is the issue of infant feeding, in which neither one of the recommended behaviours for HIV positive women - breast milk substitutes or exclusive breastfeeding and then early weaning - are normative practices. It has therefore been difficult to reach most pregnant women with the full package of PMTCT interventions (Rutenberg, Baek, Kalibala \& Rosen, 2003:3).

\section{LITERATURE REVIEW}

The literature review covers three areas of importance, namely: the national situation regarding PMTCT services, considerations relating to the target community, and the situation in the Eastern Cape Province with special reference to the regional health services.

The South African government has been conducting pilot studies in all nine provinces of South Africa to test the implementation of Nevirapine in preventing the transmission of HIV/AIDS from mother to child. The Health Systems Trust (McCoy, 2002:3) conducted a study of PMTCT services at 18 pilot sites where PMTCT services were provided. The interim findings of this study suggest that the core problems relate to lack of staff, poor infrastructure, unavailability of equipment, and negative community attitudes. The Health Systems Trust further concluded (McCoy, 2002:25f.) that many of the difficulties and constraints to full and effective implementation were systemic in nature, and related to the poor functioning of the health care system in general. Marked differences existed in implementation and uptake rates between provinces and sites. The core of these differences seems to be the large inequities in 
health care infrastructure within the country.

The study (McCoy, 2002:25f.) further found that up to as many as $15 \%$ of pregnant women currently have access to PMTCT services and that $51 \%$ of the pregnant women in the national pilot sites agreed to be tested. Of these, $30 \%$ tested HIV positive. Less than one third of the number of HIV positive pregnant women identified at the national PMTCT sites have delivered with the administration of Nevirapine to both mother and baby. The Health System Trust recommended that the provision of PMTCT acts as a catalyst for the improvement of the health care system.

Recently the narrow scope of the PMTCT approach has been questioned, as the realities of limited resources, inadequate infrastructure, and the barriers to behaviour change are being researched (Pathfinder International, 2003:3). In 2002 the United Nations, recognised that the health of mothers was not given adequate attention in traditional PMTCT programmes. It was also found that the expanded initiative should include care of mothers living with HIV/AIDS, such as provision of ARVs when appropriate, and treatment of opportunistic infections, advocacy to speed access to medicines and increased funding for women's education (UNAIDS, 2002). Ensuring confidentiality in testing, counselling and care have been highlighted. It was also highlighted that PMTCT should be designed so as not to overburden providers or facilities beyond their capabilities and capacity.

There are also other social factors that might act as barriers to the implementation of PMTCT programmes. Bassett (2002:350) noted that providing voluntary counselling and testing (VCT) would cause a major bottleneck in delivering PMTCT services on a wide scale in countries where HIV prevalence is high. Other studies claim that part of this bottleneck simply relates to the cost of delivering VCT on the scale required. In addition, there are inevitable dropouts at each step of the VCT process. Not all women will agree to be tested, and of those who are tested not all will return for their results, nor will all who learn of a HIV positive status take the necessary drugs or give birth in health facilities (Bassett, 2002:349).

The provision of free feeding formula was also felt to have a significant effect on PMTCT interventions in com- munities (UNICEF, 2003:4). With regard to Botswana, Shapiro, Lockman, Thior, Stocking, Kebarabetswe, Wester, Peter, Marlink, Essex and Heymann (2003:221) argue that because HIV remains highly stigmatised, women may choose to avoid potential disclosure of their status by feeding according to traditional practices. This might have led to some women in the formula study arm initiating breastfeeding in order to avoid disclosing their HIV status through the use of formula feeding. Stigma remains a major concern with women not wishing to have their status made public in any way. Thus, the provision of information to pregnant women remains vital, and HIV testing acceptance rates during pregnancy can be increased when women understand the modes of vertical transmission and the role of medication regimens in preventing transmission; believe that prenatal identification of HIV can promote the health of mother and child; and perceive their providers as strongly endorsing testing (Fernandez, Wilson, Ethier, Walter, Gay \& Moore, 2000:460).

Etiebet, Fransman, Forsyth, Coetzee and Hussey (2004:37) found that routine prenatal HIV testing and interventions, to reduce perinatal HIV transmission, are acceptable to the majority of women in the South African urban township of Khayelitsha, despite their awareness of a discriminatory attitude that existed in the community towards HIV-positive women. Further, Hilderbrand, Goemaere and Coetzee (2003:779) found in a cross-sectional survey of 113 women attending the PMTCT programme that over $95 \%$ of women on the programme formula-fed their infants and did not breastfeed them at all. Seventy per cent of women reported that their infants had never had diarrhoea, and only $3 \%$ of children had experienced two episodes of diarrhoea. Formula feeding seems safe and feasible in an urban environment where sufficient potable water is available.

The involvement and support from men is crucial if problem free PMTCT interventions are to be observed. The exclusion of men from reproductive health and pregnancy care is long-standing, so bringing men in into this area at this moment in time will not be simple. Bassett (2002:347) argues that men need to hear advocacy messages concerning their responsibility for caring for their families, and therefore to support their partners getting comprehensive pregnancy care, including PMTCT. 
Many governments argue that their health services are under-funded and hence are unable to provide a package of services vital to comprehensive primary health care provision. Such a package would include quality family planning, maternity and child care services. The Eastern Cape Province has undertaken to offer this package, but it faces many difficulties in delivering on the PMTCT programme. This Province is economically disadvantaged, with relatively inadequate access to services compared to the other eight provinces. In 1996, $68.3 \%$ of households in this province had insufficient electricity supply; $46.5 \%$ did not have access to basic water supply, and $35.8 \%$ did not have access to basic sanitation (RSA National Treasury, 2001:7). The population of Eastern Cape Province was estimated at 6.7 million in 1999 (RSA National Treasury, 2001:3).

The province is also lagging behind in economic development. It has the highest unemployment rate in the country (48.5\%), with a per capita disposable annual income of R7800 (\$918) (Mahlalela, Rohde, Meidany, Hutchinson \& Bennett, 2001:3). Most employed men work as migrants in Gauteng, Western Cape Province or KwaZulu-Natal. The poverty rate (percentage of population in poverty) was estimated at $63.3 \%$ (Mahlalela et al. 2001:4), the second highest in the country. The Human Development Index for the Eastern Cape was 0.51 in 1999. This is far lower than the rest of South Africa, with the exception of the Limpopo Province. Similarly, by all other socio-economic indicators the Eastern Cape is classified as a province with a high need of input to improve its economic position.

The health district boundaries are co-terminus with political boundaries. People living in each health district are expected to obtain health services within their borders. Anew infrastructure for delivery of primary health care $(\mathrm{PHC})$ has been added to existing services. The Eastern Cape Province now has a PHC infrastructure that includes 653 fixed clinics, 124 mobile clinics, 28 community health centres and 64 district hospitals. A concerted effort has been made to strengthen and upgrade PHC clinical and management skills through the Equity Project, jointly undertaken by USAID and the Eastern Cape Department of Health.

It is important that possible barriers to the uptake of PMTCT be identified so that proper ways of dealing with them are developed. Assessing the August 2003 PMTCT statistics in a sub-district in the Eastern Cape (Peltzer, Mosala, Dorkenoo \& Gumede, 2003:6), only $73 \%$ of all first antenatal visits got MTCT pre-test counselling of which $58 \%$ accepted an HIV test after counselling. From those who accepted an HIV test, 96\% returned to learn about the results. Of these, $23 \%$ tested HIV positive and almost half (46\%) got NVP. Table 1 indicates the PMTCT monitoring data for the clinics in the sub-district offering PMTCT for August 2003, serving as base line data for the present research.

An interesting finding in this table is that out of the total number of pregnant women identified in the baseline survey $58 \%$ of them accepted HIV test and $46 \%$ of them have delivered with the administration of Nevirapine to mothers. Table 1 also shows the assessment of the outcomes of pre-test and post-test counselling, such as the number of patients who receive counselling within a particular time frame, the number receiving counsel

Table 1: Monitoring and evaluation of the implementation of the PMTCT programme in five clinics for August 2003 (Peltzer et al. 2003:6)

\begin{tabular}{|l|l|l|l|l|l|l|}
\hline Item & Clinic A & Clinic B & Clinic C & Clinic D & Clinic E & Total \\
\hline $\begin{array}{l}\text { First ANC bookers before 20 } \\
\text { weeks }\end{array}$ & 10 & 16 & 10 & 28 & 2 & $66(\mathrm{n})$ \\
\hline First ANC visit 20 weeks or later & 67 & 44 & 104 & 50 & 26 & $291(\mathrm{n})$ \\
\hline Total first ANC bookers & 77 & 60 & 114 & 78 & 28 & $357(\mathrm{~N})$ \\
\hline MTCT pre-test counselling & 35 & 60 & 38 & 78 & 49 & $\begin{array}{l}260(73 \%)(\% \text { from first } \\
\text { ANC bookers })\end{array}$ \\
\hline HIV test accepted after counselling & 35 & 60 & 38 & 36 & 37 & $\begin{array}{l}\text { 206 (58\%) (\% from first } \\
\text { ANC bookers) }\end{array}$ \\
\hline HIV result received by client & 35 & 56 & 38 & 32 & 37 & $\begin{array}{l}198(96 \%)(\% \text { from } \\
\text { accepted HIV testing })\end{array}$ \\
\hline ANC client HIV +ve (first booker ) & 14 & 14 & 8 & 9 & 3 & $\begin{array}{l}48 \\
(23 \%)(\% \text { from accepted } \\
\text { HIV testing }\end{array}$ \\
\hline NVP HIV women & & & & & & $22(46 \%)(\%$ from HIV+) \\
\hline
\end{tabular}


ling and taking/not taking the test, and the number who take the test but who do or do not return for the results. In all health care facilities it is evident that more pregnant women first book at the antenatal clinic after 20 weeks of their gestation period. Seventy-three per cent of them agree to participate in the PMTCT programme and undergo pre-test counselling. It is disturbing that only $58 \%$ of pregnant women came back and got their HIV serostatus results and underwent post-test counselling. This means that if they were HIV positive, they might not ever get the Nevirapine (NVP) intervention. Further only $48(23 \%)$ of them did come back at 28 weeks of gestation to receive their Nevirapine packs in preparation for delivery at home or health care facility.

\section{RESEARCH METHOD}

\section{Design and setting}

A cross-sectional survey was carried out among pregnant women in four clinics offering PMTCT in a rural district in the Eastern Cape Province. PMTCT included according to the national protocol: health education on antiretroviral treatment and feeding options for pregnant women, voluntary counselling and testing, rapid onsite HIV testing, supply of a Nevirapine pack, free formula provision, and PMTCT integrated into antenatal care (Peltzer et al. 2003:2).

\section{Sample and procedure}

A convenient sample of all consecutively HIV post-test counselled women were recruited during a period of two month in 2003. After post-test HIV counselling, the onsite HIV counsellor in each of the four clinics referred the patient to the researcher. There were five participants who refused to participate. A final sample of 186 pregnant women (all Xhosa by ethnicity) was drawn from four clinics.

\section{Ethical consideration}

The study was approved by the Rhodes University Ethics Committee. The researcher obtained informed consent from each woman willing to participate in the research. The consent form included the permission to have access to the patient's medical records including the HIV status. The researcher accessed the HIV status from the participants by asking the clinic nurse to check the HIV register for the research participants' names. The clinic nurse then informed the researcher of the HIV status of their participants in the study. Anonymity and confidentiality of these women were assured.

\section{Questionnaire}

An existing questionnaire (Dorkenoo, Gumede, Maluleke, \& Shaikh, 2003:3-5), containing both closed and open-ended questions, was used. It provided for the following categories of data: demographic and socioeconomic data ( 9 items), availability of water, transport and communication (8 items), exposure to PMTCT components (14 items), satisfaction with counselling (5 items), family and community support for pregnancy (14 items), delivery options ( 3 items), feeding options (4 items), and quality of PMTCT (10 items). The questionnaire had been developed and piloted in an earlier study on PMTCT in Gauteng Province (Dorkenoo, Gumede, Maluleke, \& Shaikh, 2003:3-5). A Cronbach alpha of 0.72 was obtained for the 4 PMTCT questions and a Cronbach alpha of 0.80 for the satisfaction with counselling questions. Interviews were conducted in isiXhosa.

\section{DATA ANALYSIS}

For the closed-ended questions descriptive statistics were calculated using SPSS version 11. To test differences between HIV positive and negative women, the Pearson Chi-Square or t-tests were used. For the openended questions a thematic analysis was used to analyse and interpret the data.

\section{LIMITATIONS}

The fact that interviews were conducted by nurses with patients in a health facility may have prompted participants to give a perceived positive response on the questions on satisfaction with health care services. In addition, the study was cross-sectional and thus no causative inferences can be made.

\section{RESULTS}

\section{Sample characteristics}

From the total of 186 pregnant women interviewed 55 
(29.6\%) were HIV positive and 131 (70.4\%) were HIV negative. Their mean age was 26.5 years $(S D=7.1)$, ranging from 15 to 50 years. The mean level of formal years of education was 7.3 years ( $S D=3.4$ years). HIV positive participants had a lower educational level than HIV negative women. The majority of HIV positive women $(62 \%)$ were not married or not living with a partner and the majority of HIV negative women (55\%) were married. Women had a mean of 3.5 dependent persons of which 2.5 were her natural children in their household. More HIV positive women (87\%) than HIV negative women $(74 \%)$ were living in a traditional African hut (see
Table 2).

Most women (81.2\%) were not formally employed (housewives), $7 \%$ were self-employed, $6.5 \%$ employed part-time, $1.6 \%$ employed full-time, and $3.8 \%$ were students. More than half of the pregnant women (57.5\%) were living with their parents, $41.4 \%$ with siblings, $34.4 \%$ with their partner or husband, $12.9 \%$ with their in-laws, $57.5 \%$ with their own children, $20.4 \%$ with other people's children and $6.5 \%$ with their grandchildren.

\section{Table 2: Sample characteristics}

\begin{tabular}{|c|c|c|c|}
\hline ITEMS & $\begin{array}{l}\text { HIV POSITIVE } \\
(n=55)\end{array}$ & $\begin{array}{l}\text { HIV NEGATIVE } \\
(n=131)\end{array}$ & $x^{2}[t]$ \\
\hline \multicolumn{4}{|c|}{ AGE } \\
\hline Average and SD for age & $\begin{array}{l}27.0 \\
(S D=6.5)\end{array}$ & $\begin{array}{l}26.3 \\
(\mathrm{SD}=7.33)\end{array}$ & {$[.55]$} \\
\hline \multicolumn{4}{|c|}{ EDUCATIONAL LEVEL } \\
\hline $\begin{array}{l}\text { Average and SD for educational level (from } \\
1=\text { no schooling to } 15 \text { university degree) }\end{array}$ & $\begin{array}{l}6.4 \\
(S D=3.3)\end{array}$ & $\begin{array}{l}7.6 \\
(S D=3.5)\end{array}$ & {$\left[-2.12^{*}\right]$} \\
\hline \multicolumn{4}{|c|}{ MARITAL STATUS } \\
\hline Married/cohabitating & $21(38.2 \%)$ & $72(55.0 \%)$ & $4.36^{*}$ \\
\hline Never married/widowed/divorced/separated & $34(61.8 \%)$ & $59(45.0 \%)$ & \\
\hline \multicolumn{4}{|c|}{ DEPENDANTS } \\
\hline $\begin{array}{l}\text { Average number (and SD) of financially } \\
\text { dependent people in the house }\end{array}$ & $\begin{array}{l}6.4 \\
(\mathrm{SD}=3.3)\end{array}$ & $\begin{array}{l}7.6 \\
(S D=3.5)\end{array}$ & {$[.83]$} \\
\hline $\begin{array}{l}\text { Average number (and SD) of these } \\
\text { dependents that are yours? }\end{array}$ & $\begin{array}{l}2.3 \\
(\mathrm{SD}=3.4)\end{array}$ & $\begin{array}{l}1.8 \\
(\mathrm{SD}=2.0)\end{array}$ & {$[1.21]$} \\
\hline \multicolumn{4}{|c|}{ HOUSING } \\
\hline Live in brick house & $7(12.7 \%)$ & $34(26.4 \%)$ & $4.14^{*}$ \\
\hline $\begin{array}{l}\text { Live in traditional African hut (round mud } \\
\text { house) }\end{array}$ & $48(87.3 \%)$ & $97(73.6 \%)$ & \\
\hline
\end{tabular}

\section{Water, transport and communication}

The baseline measures included questions related to factors influencing access to PMTCT services at a primary care facility as well as the referral to hospitals. These include: availability of potable water, transport availability and communication. Two-thirds of the women $(66.1 \%)$ get their water from rivers and streams and a quarter (24.7\%) from a source, while on $14.5 \%$ had access to tap water. The most common means to travel to the hospital or clinic was to walk, followed by public transport (bus or taxi). Thirty-nine percent of the respondents spend up to 30 minutes to get to the clinic, $26 \%$ up to an hour and another $36 \%$ more than one hour. From those participants who used transport to the clinic most used less than five Rand, followed by five to six Rand and seven to ten Rand. The money used for transport to the clinic was in most cases taken from parents or grandparents, followed by the husband/ boyfriend, other relatives and self. Less than half of the 
women (45\%) had access to a telephone and only $24 \%$ had access to a phone at night (see Table 3).

\section{EVALUATION OF PMTCT}

As indicated by Table 4 more than $90 \%$ of the participants felt that they had received adequate information on most of the PMTCT components such as HIV testing, counselling, confidentiality, Nevirapine dosage, feeding options and disclosure of HIV status to spouse. Items which were not sufficiently addressed during PMTCT were, in descending order: (1) advantages and disadvantages of disclosure of HIV status (29\%), (2) disclosure of HIV status to family (27\%), (3) transmission of HIV through breast milk (18\%), HIV prevention (11\%), and HIV/AIDS related illnesses (11\%) (see Table 4 on page 36 ).

About $90 \%$ of all participants were satisfied with the HIV counselling they had received as evidenced by the information provided regarding, having felt understood by the counsellor, having had an opportunity to express their concerns, and their privacy having been considered during the session. Most (87\%) of the participants also indicated that they wanted more time with the counsellor (see Table 5 on page 37).

Most women considered the health care staff as friendly $(66.5 \%)$ or very friendly $(24.9 \%)$, while some $(7.6 \%)$ evaluated them as unfriendly and $2(1.1 \%)$ as very unfriendly.

\section{Support during pregnancy and in the community}

Most women (54\%) felt they would have support during their pregnancy from their mothers, followed by their husbands/partners (50\%), other family members (19\%), mothers-in-law (13\%) and health workers (8\%). Onefifth of the pregnant women indicated having knowledge of a PMTCT support group (see Table 6 on page 37).

\section{Delivery and feeding of the baby}

Most pregnant women (92\%) prefer to give birth in hospital while $8 \%$ prefer to deliver at home, mostly with the assistance of a TBA. In case of complications during delivery $9 \%$ would consult the TBA and $91 \%$ the hospital.
Two-thirds of the HIV positive women would feed their baby with formula milk only. Breast and formula feeding are the most preferred methods of feeding babies for HIV negative women (84\%) though $27 \%$ of the HIV positive women were also planning on doing so (see Table 7 on page 38 ).

\section{RESULTS TO OPEN-ENDED QUESTIONS}

Responses from the open-ended questions are presented according to the questions as follows:

Would you return to the same clinic for similar services?

How could services for pregnant women be improved? What are the community's attitudes towards people living with HIV/AIDS?

Have you had contact with any of the volunteer(s) providing outreach services for PMTCT or HIV in your community?

Should you become pregnant again, would you be willing to participate in the VCT programme again?

\section{Returning to the same clinic for similar services}

All the participants stated, when asked, that they would return to the clinic for the same service. The major motivation for this seems to be that the attitude of health providers made it easier and useful for them to return to the health facility. They expressed excitement about the type of education they received from the health providers and indicated that health providers informed them about appropriate health practices, including the practice of safe sex and about starting their own vegetable gardens. Another reason was willingness to learn about health matters, especially those related to HIV/AIDS. Participants praised the nursing staff for the appropriate environment they create for learning and said that the staff was friendly and accepted them for who they are. Evidence regarding the reasons for returning to the clinic was as follows: "I am encouraged by teachings about HIVIAIDS. Now that I know I am HIV positive the nurses are going to give me help and support." "To get more lessons about PMTCT. To receive advice from the nurses." "Now that I have been found to be HIV positive I want to get advice every now and then. I wish to get an HIV negative baby if possible." 
Table 3: Number of all pregnant women (HIV positive and negative) who have access to water, transport and communication $(\mathrm{N}=186)$

\begin{tabular}{|c|c|c|}
\hline ITEMS & & $\%$ \\
\hline \multicolumn{3}{|c|}{ Where do you get drinking water? (multiple responses possible) } \\
\hline Tap & 27 & 14.5 \\
\hline River & 123 & 66.1 \\
\hline Source & 46 & 24.7 \\
\hline \multicolumn{3}{|c|}{ Mode of transport to get to hospital (multiple responses possible) } \\
\hline Walk & 118 & 63.4 \\
\hline Bus & 75 & 40.3 \\
\hline Taxi & 53 & 28.5 \\
\hline Own car & 3 & 1.6 \\
\hline Hired car & 1 & 0.5 \\
\hline Hitch-hiking & 9 & 4.8 \\
\hline Cart & 1 & 0.5 \\
\hline \multicolumn{3}{|c|}{ Mode of transport used to clinic today (multiple responses possible) } \\
\hline Bus & 54 & 29.0 \\
\hline Taxi & 47 & 25.2 \\
\hline Walk & 91 & 43.5 \\
\hline Hitch hiked & 2 & 1.0 \\
\hline \multicolumn{3}{|c|}{ Time it takes to get to clinic today } \\
\hline 30 minutes and less & 72 & 38.7 \\
\hline$>30$ minutes to 1 hour & 48 & 25.8 \\
\hline$>1$ hour to $1 \frac{1}{2}$ hours & 28 & 15.1 \\
\hline$>1 \frac{1}{2}$ hours & 38 & 20.4 \\
\hline \multicolumn{3}{|c|}{ Cost of one-way trip (excluding walking)\# } \\
\hline R 2.50 to $\mathrm{R} 4.00$ & 53 & 28.5 \\
\hline$>$ R 4.00 to $\mathrm{R} 6.00$ & 36 & 19.4 \\
\hline > R 6.00 to $\mathrm{R} 10.00$ & 24 & 12.3 \\
\hline \multicolumn{3}{|c|}{ Where did you get money from to get to the clinic today? (excluding walking)\# } \\
\hline Self & 9 & 4.8 \\
\hline Husband/boyfriend & 32 & 17.2 \\
\hline Parents/grandparents & 42 & 22.6 \\
\hline Other relatives & 10 & 5.4 \\
\hline Grant support & 3 & 1.6 \\
\hline Other (siblings, neighbours) & 4 & 2.2 \\
\hline \multicolumn{3}{|l|}{ Access to telephone } \\
\hline Yes & 84 & 45.2 \\
\hline If, yes: Own telephone & 32 & 17.2 \\
\hline Other private telephone & 25 & 13.4 \\
\hline Public telephone & 29 & 15.6 \\
\hline $\begin{array}{l}\text { Access to own or other private telephone or public phone } \\
\text { at night }\end{array}$ & 44 & 23.6 \\
\hline
\end{tabular}

\#Sample only includes participants who are not walking. 
Table 4: Adequate information on PMTCT provided by the health care provider in affirmative responses in percentage of all responses $(\mathrm{N}=186)$

\begin{tabular}{|l|l|}
\hline \multicolumn{1}{|c|}{ TTEMS } & $\%$ \\
\hline Testing for HIV & 99.5 \\
\hline Your right to consent for the HIV test & 99.5 \\
\hline Aocess to ongoing counselling & 97.8 \\
\hline HIVIAIDS related illnesses & 89.2 \\
\hline How you and your family can protect yourselves from HIV/AIDS & 99.2 \\
\hline Transmission of HIV through breast milk & 81.7 \\
\hline Feeding options to prevent your child from getting HIV infected & 96.8 \\
\hline Advantages and disadvantages of disclosure of HIV status & 71.0 \\
\hline Disclosure of HIV status to family & 72.6 \\
\hline Disclosure of HIV status to spouse & 94.6 \\
\hline Spouse counselling & 98.4 \\
\hline Confidentiality & 97.3 \\
\hline Nevirapine dosage & 97.8 \\
\hline Health education & 95.7 \\
\hline
\end{tabular}

The optimistic attitude from the HIV+ women might indicate a generally supportive approach from clinic staff and a non-discriminatory attitude.

\section{Improvement of services for pregnant women}

The major concern of participants regarding the service rendered was adequacy of nursing staff. It was also indicated that a doctor is needed at the clinics, even if only twice a week. These requests were noted in two ways, firstly the women wanted the extended waiting times reduced and some of the women felt that they needed more care and attention. The need for ambulances in case of emergencies was also raised.

The following data units support this category: "There is only one nurse here. Each time I come here I only see one nurse. They must add more nurses, doctors and transport to take us to the hospital when sick." "Staff shortage needs to be addressed; it results to long waits. There must be a doctor for clients. There must be privacy when doing counselling."

The shortages of staff meant long waiting periods in a cold waiting room, without any refreshments. Suggestions were made that the clinics/hospital needed to protect women against cold weather by providing heaters and tea and coffee when it is cold. Other participants complained about lack of space, entertainment and chairs while waiting: "In winter its cold and we would like to have heaters installed. We need a spacious room, TV to watch while we are waiting for services. Add more nurses." "We want to be kept warm we need a spacious room. We need gowns to cover ourselves while being palpated." "We need more space while waiting. We need a radio and TV. Something to keep us warm while waiting. More staff because we stay here for a long time."

\section{Community attitudes towards people liv- ing with HIV/AIDS (PLWHAs)}

The dominant response of the pregnant women was that people living with HIV/AIDS are not accepted by the community. PLWHAs are often spoken about in the community, and people avoid being associated with them. Others said people living with HIV/AIDS are often isolated and in their households they are not al- 
Table 5: Satisfaction with counselling components in affirmative responses by HIV status

\begin{tabular}{|c|c|c|c|}
\hline ITEMS & $\begin{array}{l}H I V(+) \\
(n=55)\end{array}$ & $\begin{array}{l}H I V(-) \\
(n=131)\end{array}$ & $x^{2}$ \\
\hline $\begin{array}{l}\text { Did you get a chance to express your needs, views } \\
\text { and concerns? }\end{array}$ & $49(89.1)$ & $106(80.9)$ & 1.86 \\
\hline $\begin{array}{l}\text { Do you feel that the information you received was } \\
\text { enough? }\end{array}$ & $52(94.5)$ & $122(93.1)$ & .13 \\
\hline Did you feel understood by the counsellor? & $54(98.2)$ & $128(97.7)$ & 04 \\
\hline Did you want more time with the counsellor? & $50(90.9)$ & $110(84.0)$ & 1.55 \\
\hline Was the session conducted in privacy & $54(98.2)$ & $112(85.5)$ & $6.50^{*}$ \\
\hline
\end{tabular}

*p<,05

Table 6: Support during pregnancy in affirmative responses in percentage of all responses ( $N=186)$

\begin{tabular}{|l|l|}
\hline Item & $\%$ \\
\hline Mother & 54.3 \\
\hline Husband/partner & 49.5 \\
\hline Other family members & 19.4 \\
\hline Mother-in-law & 12.9 \\
\hline Health workers & 8.1 \\
\hline Community members & 2.7 \\
\hline Friends & 1.6 \\
\hline Traditional birth attendants (TBAs) & 1.1 \\
\hline Other & 5.9 \\
\hline Know PMTCT (or HIV) support group & 25.8 \\
\hline
\end{tabular}

lowed to share household utensils with other family members. They are often not allowed by their family members to attend social gatherings - even church.

Some said they do not know anyone with HIV/AIDS in their communities, though they hear that they are treated badly. These views were held both by women who were diagnosed as HIV positive and those who were found to be HIV negative as indicated by the following evidence: "They are treated badly. People call them with bad names. Most of the time they stay alone in their houses and are not cared for. They have sepa- rate eating utensils reserved for them in their homes." (HIV+). "People are scared of them because they think they will be infected. If there is a wedding or a traditional gathering they don't invite them to be part of it." "They are laughed at by their friends. Others give them names and others point at them and say they have three letters." (HIV+). "I don't see them because they are unknown; they stay alone. People dislike them." (HIV+).

Not all participants held similar views about treatment of PLWHAs in the community. A smaller number of 
Table 7: Delivery and feeding options by HIV status in frequency (and percent)

\begin{tabular}{|c|c|c|c|}
\hline ITEMS & $\begin{array}{l}\text { HIV (+) } \\
(n=55)\end{array}$ & $\begin{array}{l}\text { HIV(-) } \\
(n=131)\end{array}$ & $x^{2}$ \\
\hline \multicolumn{4}{|c|}{ Where do you prefer to give birth? } \\
\hline Hospital & $50(90.9)$ & $122(93.1)$ & .27 \\
\hline Home & $5(9.1)$ & $9(6.9)$ & \\
\hline If birth at home, would you call a TBA to assist & $44(80.0)$ & $113(86.3)$ & 1.15 \\
\hline \multicolumn{4}{|c|}{ Where would you, in case of complications, give birth after hours? } \\
\hline Hospital & $50(90.9)$ & $117(90.0)$ & \\
\hline TBA & $5(9.1)$ & $11(8.5)$ & .87 \\
\hline \multicolumn{4}{|c|}{ Feeding methods to be used } \\
\hline Breast feeding & $5(9.1)$ & $14(10.7)$ & \\
\hline Formula feeding & $35(63.6)$ & $7(5.3)$ & \\
\hline Breast and formula feeding & $15(27.3)$ & $110(84.0)$ & \\
\hline
\end{tabular}

participants felt that they were well cared for: "They are welcome. They are treated well. People respect them. They give them confidence to go to the clinic and help them with their needs." "They are welcome with love. People support them with food, that is fruit and vegetables. They encourage them to join support groups. They help with cleaning their clothes and their bodies."

\section{Community HIV supporters}

In response to a question concerning contact with volunteer services, the majority of participants said they have neither seen volunteers, nor are they aware of the volunteer activities in the community. Those who have seen them said they teach the communities about HIV/ AIDS, starting vegetable gardens and they encourage people to come to the clinic. Fourteen (25.5\%) of the HIV positive and 46 (35.1\%) of the HIV negative women had been in contact with volunteers educating people on PMTCT and HIV in the community. Evidence in this regard includes: "They do HIVIAIDS awareness campaigns. They teach us to use safer sex practices. They do health promotion on good nutrition. They teach about growing vegetables, health promotion and personal environmental hygiene." "They teach us about the prevention of babies by giving Nevirapine syrup at birth to an HIV positive mother. They teach us about safe sex. They teach us about how to care for people who are already infected with HIVIAIDS."

\section{Repeat of VCT}

Finally, participants were asked whether, should they become pregnant again, they would be willing to participate in the VCT programme again. Both HIV negative and HIV positive women answered this question, though it was meant primarily for the former group. Seven (12.\%) of the HIV positive women said "no", mostly as they knew their status and had decided not to have another child. All of the HIV negative women said "yes". The main reasons, given by the HIV negative women, for willingness to do VCT were that they needed advice from health workers about feeding methods, to monitor the health and well-being of their babies from birth, and to be sure of their status; so that if they are found to be HIV positive they can get help immediately from the clinic: "I want to prevent transmission of HIV from a mother to a child. I want to learn more information about this PMTCT." "Since I have been found to be HIV negative I have been encouraged to continue like this so as to keep my baby safe. I am also encouraged to always know my status as I wish to remain negative." "To pre- 
vent my child from being infected. To prevent further infections. To be educated on how to prolong my life and not give up in life because I am (HIV) infected."

\section{DISCUSSION}

The utilisation of PMTCT (the acceptance of antiretroviral therapy to HIV positive women, facility-based delivery where improved obstetric practices can be used, and ART for mother and newborn can be supervised, and adherence to "take-home" ART for mother and newborn when given to HIV positive women at ANC), can be attributed to factors such as: (1) HIV counselling by the health care staff, (2) physical access to the health facility, (3) family and community support, (4) stigma, (5) delivery preference, and (6) infant feeding preferences.

\section{HIV counselling by health care staff}

The evaluations of the PMTCT services in the clinics appear fairly positive. Almost $100 \%$ of women felt the counselling was excellent and that they received adequate information on all aspects of PMTCT. Many would have liked more time with the counsellor. More than $90 \%$ felt that the staff was friendly. This was born out by all the participants agreeing that if they were in the same situation they would come back to the clinic for the same services. Earlier research and observation seemed to generally support these positive attitudes, and that the majority of the counsellors had the necessary repertoire of skills (Maluleke, 2003:15f.).

\section{Physical access to health facility}

The clinic structures and health services themselves received more criticism, with virtually all clients feeling that the clinics are understaffed. This led to excessive waiting times, which are rendered uncomfortable by the cold boring waiting rooms. Access to health facilities is a problem, especially as regards transport during emergencies. With a geographically dispersed community it is generally difficult to get to the clinics even during the day. More than one-third of the sample spent more than one hour to get to the nearest clinic. There is very little public transport, and emergency transport is difficult to contact.

\section{Family and community support}

Half of the participants acknowledged family support during pregnancy to include their mother and husband or partner. Volunteers were seen as useful, although there appeared to be uncertainty surrounding them. Many claimed not to have met volunteers or to have heard of them. It is likely that, due to small numbers, the influence of volunteers' contribution is not widely known of. Those who did know about volunteers spoke highly of the services they provide.

\section{Stigma}

Stigma and active acts of discrimination are a problem in the community. Most of the women spoke of PLWHAs as being isolated, insulted, excluded from family and community events, or having fear shown towards them. A smaller group felt that PLWHAs were accepted. In a similar study of pregnant women within the PMTCT programme in Gauteng Dorkenoo et al. (2003:20f.) also found that a stigma persists at the family and at community level. Women indicated that their partners and other family members did not support them emotionally. Community education and awareness campaigns on PMTCT are essential components for the success of the programme. Such education should reinforce male involvement and other family members, particularly mothers-in-law, who have influence over the options open to women who are HIV positive.

\section{Delivery preference}

Most pregnant women (92\%) preferred to give birth in hospital, while $8 \%$ prefer to deliver at home, mostly with the assistance of a Traditional Birth Attendant (TBA). In this regard, O'Mahony and Steinberg's (1995:1168) findings are quite the opposite. In a survey of two hundred women on the place of delivery (in rural Transkei, now part of the Eastern Cape Province), with reference to their most recent delivery, two-thirds indicated that they had delivered at home and one-third within the health services. Of those who delivered at home, $62(47 \%)$ were alone at the time of delivery while the remainder were assisted by a close relative or neighbour; $38 \%$ had one or more risk factors for obstetric complications (O'Mahony \& Steinberg, 1995:1168).

Use of skilled professional childbirth attendants by all women remains a goal of safe motherhood programmes, 
despite well-known barriers. Increasing use of skilled professional childbirth attendants and facility-based child health when feasible should also be a behavioural goal of PMTCT programmes. This would allow timely, supervised receipt of antiretrovirals during the intrapartum period, while at the same time allowing opportunity for quality routine childbirth care, and improved obstetric practice administered by skilled providers (Moore, 2003:27). However, partly due to the magnitude of MTCT and the urgency of increasing coverage of PMTCT interventions, and taking into account the childbirth realities in much of rural Africa, many programmes have begun to focus efforts on improving obstetric practices among traditional birth attendants (TBAs) during homebased childbirth. Challenging global consensus on the diminishing need for and role of TBAs, some PMTCT programmes have placed TBAs at the centre of efforts to reduce PMTCT in the community. For the most part, this includes reinforcing quality home-based maternity care by TBAs and other family birth attendants and avoidance of home birth practices that could increase MTCT (Moore, 2003:27).

\section{Infant feeding preferences}

Two-thirds of the HIV positive women would feed their baby with formula milk only. Breast and formula feeding is the most preferred methods of feeding babies for HIV negative women (84\%), though, $27 \%$ of the HIV positive women were also planning to do so. Lack of access to tap water would also make it more difficult to do formula feeding. Transmission of human immunodeficiency virus type 1 (HIV-1) through breastfeeding has been conclusively demonstrated. The risk of such transmission has been quantified, the timing has been clarified, and certain risk factors for breastfeeding transmission have been identified. In areas where infant formula is accessible, affordable, safe, and sustainable, avoidance of breastfeeding has represented one of the main components of mother-to-child HIV-1 transmission prevention efforts for many years. In areas where affordable and safe alternatives to breastfeeding may not be available, interventions to prevent breastfeeding transmission are being investigated (Read, 2003:1200f.).

\section{CONCLUSION AND RECOMMENDA- TIONS}

In this study regarding the resource poor rural setting in the Eastern Cape Province of South Africa the final recommendations are made.

Health care staff should provide quality HIV counselling and undergo refresher courses on PMTCT.

Physical access to health facilities, especially for delivery, should be improved by for example, providing refunds for bus fares to get to the clinic and communication access should be improved to call for ambulance services.

Family and community support should be improved for PLWHAs by, for example, peer support groups and training of community counsellors,

Stigma in health care settings and the community needs should be recognised and addressed by PMTCT programme managers by, for example, fostering couple and community discussion on HIV and by normalising HIV counselling, testing and care.

Pregnant women should be encouraged to deliver with skilled birth attendants and traditional birth attendants should be trained on safe delivery and HIV and ART.

Infant feeding counselling needs to be improved and access to potable water for formula feeding should be made available.

\section{Acknowledgements}

Funding from the Ford Foundation for this project is hereby acknowledged. The anonymous reviewers are thanked for their useful comments.

\section{REFERENCES}

BASSET, MT 2002: Ensuring a public health impact of programs to reduce HIV transmission from mothers to infants: the place of voluntary counselling and testing. American Journal of Public Health, 92(3): 347-351.

DEPARTMENT OF HEALTH 2000: HIV/AIDS Policy Guidelines. Prevention of mother-to-child HIV transmission and management of HIV positive pregnant women. Pretoria: Department of Health. DEPARTMENT OF HEALTH 2003: Summary Report: National HIV and syphilis antenatal sero-prevalence survey in South Africa. Pretoria: Department of Health.

DORKENOO, E; GUMEDE, T; MALULEKE, K \& SHAIKH, N 2003: 
Prevention of mother-to-child transmission: a report of an assessment of a pilot programme in 15 health facilities in Gauteng Province. Cape Town: Human Sciences Research Council. ETIEBET, MA; FRANSMAN, D; FORSYTH, B; COETZEE, N \& HUSSEY, G 2004: Integrating prevention of mother-to-child HIV transmission into antenatal care: learning from the experiences of women in South Africa. AIDS Care, 16(1):37-46.

FERNANDEZ, MI; WILSON, TE; ETHIER, KA; WALTER, EB; GAY, CL \& MOORE, J 2000: Acceptance of HIV testing during prenatal care. Perinatal Guidelines Evaluation Project. Public Health Reports, 115(5):460-468.

HILDERBRAND, K; GOEMAERE, E \& COETZEE, D 2003: The prevention of mother-to-child HIV transmission programme and infant feeding practices. South African Medical Journal, 93(10): 779-81.

MAHLALELA, X; ROHDE, J; MEIDANY, F; HUTCHINSON, P \& BENNETT, J 2001: Primary Health Care in the Eastern Cape Province, 1997-2000. Bisho: Eastern Cape Department of Health, South Africa.

MALULEKE, R 2003: Eastern Cape HIV counsellors report. Pretoria: Ford Foundation.

MCCOY, D 2002: Interim findings on the national PMTCT pilot sites: Lessons and recommendations. Durban: Health Systems Trust. MOORE, M 2003: A behavior change perspective on integrating PMTCT and safe motherhood programs: a discussion paper. Washington, DC: The Change Project: AED/The Manoff Group.

O'MAHONY, D \& STEINBERG, M 1995: A population-based survey of obstetric practices among rural women in the Bizana district, Transkei. South African Medical Journal, 85(11):1168-71. PATHFINDER INTERNATIONAL 2003: Integrating prevention of mother to child HIV transmission into existing maternal child and reproductive health programs. New York: Pathfinder International. PELTZER, K; MOSALA, T; DORKENOO, E \& GUMEDE, T 2003: Health facility baseline report on Preventing Mother-To-Child Transmission (PMTCT) in a district of the Eastern Cape. Johannesburg: Ford Foundation.

READ, JS 2003: Human milk, breastfeeding, and transmission of human immunodeficiency virus type 1 in the United States. American Academy of Pediatrics Committee on Pediatric AIDS. Pediatrics, 112(5):1196-1205.

RSANATIONAL TREASURY 2001: RSA National Intergovernmental Fiscal Review 2001. Cape Town: Formeset Printers.

RUTENBERG, N; BAEK, C; KALIBALA, S \& ROSEN, J 2003: Evaluation of United Nations-supported pilot projects for the prevention of mother-to-child transmission of HIV. New York: UNICEF.

SHAPIRO, RL; LOCKMAN, S; THIOR, I; STOCKING, L; KEBARABETSWE, P; WESTER, C; PETER, T; MARLINK, R; ESSEX, M \& HEYMANN, SJ 2003: Low adherence to recommended infant feeding strategies among HIV-infected women: results from the pilot phase of a randomized trial to prevent mother-to-child transmission in Botswana. AIDS Education and Prevention, 15(3): 21-230.

UNAIDS 2002: Report on the global HIV/AIDS epidemic, July 2002. Geneva: UNAIDS.

UNICEF 2003: Mother-to-Child transmission of HIV/AIDS.

www.unicef.org/programme/hiv/focus/mtct/mtct.htm. Accessed 18 September 2003

WHO 2001: Prevention of mother-to-child transmission of HIV. Geneva: WHO. 